\title{
INCIDENCE OF MICRODELETIONS IN THE AZF REGION OF THE Y CHROMOSOME IN SLOVAK PATIENTS WITH AZOOSPERMIA
}

\author{
Regina Behulova ${ }^{\mathrm{a}}$, Ivan Varga ${ }^{\mathrm{b}, \mathrm{c}, \mathrm{d}}$, Lubica Strhakova ${ }^{\mathrm{e}}$, Alexandra Bozikova ${ }^{\mathrm{f}}$, Dana Gabrikova $^{\mathrm{f}}$, \\ Iveta Boronova ${ }^{\mathrm{f}}$, Vanda Repiska ${ }^{\mathrm{a} *}$
}

a Institute of Medical Biology, Genetics and Clinical Genetics, Faculty of Medicine, Comenius University, Bratislava, Slovakia

${ }^{b}$ Institute of Histology and Embryology, Faculty of Medicine, Comenius University, Bratislava, Slovakia

c Institute of Histology and Embryology, Faculty of Medicine, Slovak Medical University, Bratislava, Slovakia

d Department of Laboratory Medicine, St. Elisabeth University of Health and Social Sciences, Bratislava, Slovakia

e Department of Clinical Genetics, Medirex Inc., Bratislava, Slovakia

$f$ Department of Biology, Faculty of Humanities and Natural Sciences, University of Presov, Presov, Slovakia

E-mail:vanda.repiska@fmed.uniba.sk

Received: June 6, 2010; Accepted with revision: December 15, 2010

Key words: Azoospermia/Y chromosome/AZF region/microdeletion/DNA analysis.

Aims. The Y chromosome accumulates male-related genes including sex-determining region of Y-chromosome (SRY) and several spermatogenesis-related genes. The long arm contains azoospermia factor (AZF) region (including sub-regions $\mathrm{AZFa}, \mathrm{AZFb}$ and $\mathrm{AZFc}$ ). Microdeletions in this region are responsible for azoospermia and oligospermia and result in the male infertility. The aim of this study was to analyze incidence of microdeletions in the AZF region of Y chromosome in patients with azoospermia from Slovakia.

Patients and Methods. Over the period from 2005 to 2009 a total of 239 men (mean age 31.74 years) were analyzed. The diagnosis of azoospermia was established on the basis of semen analysis. All patient samples were analyzed cytogenetically. Chromosomal analysis was performed on all patients on cultured lymphocytes from peripheral blood. For exact diagnosis of microdeletions in AZF region we used a PCR-method using a set of sequence-tagged sites from all AZF sub-regions (according to the recommendation by the European Academy of Andrology and the European Quality Monitoring Network Group).

Results. Among our 226 patients with azoospermia and with normal karyotype, 8 patients (mean age 30.6 years) had microdeletions in the AZF region of the Y chromosome (3.35\%). Considering particular types of deletions we determined deletions in each region AZFa,b,c but also a complete deletion of the entire AZF region. The presence of microdeletion(s) in the AZFc region was the most frequent. In our study we found 12 patients (5\%) with 47,XXY karyotype (Klinefelter syndrome), but these patients didn't have microdeletion of Y chromosomes.

Conclusion. The study confirmed that percentage of microdeletions in the AZF region is low in Slovak azoospermic patients, but important from a prognostic view.

\section{INTRODUCTION}

The human Y chromosome (60Mb long) is essential for human sex determination and male germ cell development and maintenance ${ }^{1,2}$. To date, 122 genes and 110 pseudogenes have been identified in the $\mathrm{Y}$ chromosome. However, the exact role of these genes in spermatogenesis has not been elucidated. Microdeletions that cause spermatogenesis impairment usually include more than one gene, so that the role of each deleted gene cannot be specified $^{3}$. Tiepolo and Zuffardi in 1976 were the first to hypothesize a correlation between Y chromosome deletions and male infertility. They suggested that deletions of Y chromosomes were the cause of azoospermia and they postulated that a genetic factor located in $\mathrm{Y}$ chromosome long arm locus 11 (Yq11) was important for male germ cell development ${ }^{4}$. Interstitial microdeletions in the euchromatic portion of the Y chromosome long arm occurs in $10-15 \%$ of idiopathic primary testiculopathies (azoospermia and severe oligozoospermia) ${ }^{5,6}$.
In 1996, Vogt et al identified three recurrently deleted regions in Yq11 termed the azoospermia factor $(\mathrm{AZF})^{7}$. The AZF region is subdivided into three non-overlapping sub-regions called $\mathrm{AZFa}$ in the proximal portion, $\mathrm{AZFb}$ in the intermediate region and $\mathrm{AZFc}$ in the distal region. The final number of genes in the above mentioned subregions of the AZF locus was determined only after defining the complete sequence of the Yq11 region in 2003. It was found that in the AZF region there are located 31 Y-specific genes which are expressed in human testes and are located in some of the other described sub-regions. 14 genes are protein-coding and 17 represent non-proteincoding transcripts ${ }^{8-10}$. Although there is still no definitive consensus about the relationship between the type of microdeletion and the resulting sperm defect, microdeletions in AZFa lead mostly to Sertoli cell-only syndrome, mutations in $\mathrm{AZFb}$ provoke an interruption in meiosis I, and mutations in AZFc result in hypospermatogenesis, progressing to severe azoospermia or oligospermia ${ }^{11-13}$. 
Our study aimed at determining the incidence of the $\mathrm{Y}$ chromosome AZF region microdeletions in patients with azoospermia from Slovakia, Europe. We analyzed each sub-region of the AZF region, because Y chromosome microdeletions cannot be predicted on the basis of clinical findings or even the results of semen analyses.

\section{PATIENTS AND METHODS}

Over the period from 2005 to 2009 a total of 239 patients from Slovakia with azoospermia were referred to our Institute of Clinical Genetics for examination of Y-chromosomal microdeletions of the AZF region. All patients were Caucasians from different regions of Slovakia. The mean age of patients was 31.74 years. Semen analyses (sperm concentration, motility, viability and morphology) were performed according to the World Health Organization Guidelines. Selection criteria were stringent; we were analyzing only the patients with azoospermia or with pathological karyotype. Most of these subjects were classified as idiopathic. Patients were excluded from the study if they had congenital absence of the vas deferens, obstructive azoospermia, infertility caused by cystic fibrosis, testicular tumors or were undergoing chemo- or radiotherapy. Our study was approved by the local ethics committee of our medical faculty.

All patient samples were analyzed cytogenetically. Chromosomal analysis was performed on all patients on cultured lymphocytes from peripheral blood using standard methods. Minimally, 40 metaphases per subject were analyzed. The chromosomal abnormalities were described according to the International System for Human Cytogenetic Nomenclature standards. Together with the analyzed group of patients we examined 50 women and 50 healthy men as negative controls, where the number of sperm in the ejaculate was higher than 20 million per milliliter.

The European Academy of Andrology (EAA) and the European Molecular Genetics Quality Network (EMQN) published the laboratory guidelines for molecular analysis of Y-chromosomal microdeletions ${ }^{14}$. Therefore we decided to alter previously used sequences and proceed in accordance with European guidelines, in which all three subregions are represented by Y sequences: sY84, sY86, sY127, sY134, sY254 and sY255.

In total, 239 patients were analyzed for the presence of microdeletions in the AZF region. Samples comprised isolated DNA from the patient's peripheral blood lymphocytes (native or frozen, in $0.5 \mathrm{ml} 0.5 \mathrm{M}$ EDTA solutions). DNA was isolated using a commercial set FlexiGene DNA Kit (Qiagen, Germany).

PCR amplification was performed on the thermal cycler (MJ Research, USA). We performed either the duplex PCR with two fragments or two multiplex PCR with five fragments. Each duplex or multiplex PCR encompassed control SRY and ZFY/X fragments. Analysis was always performed with a male control sample, a female control sample and a blank sample. Negative results were confirmed only after three amplification failures. We repeated amplification on new DNA extracted from a second sample and each STS was analyzed separately in single PCR.

PCR products were separated electrophoretically in $2 \%$ agarose gel at laboratory temperature, in TBE buffer at $200 \mathrm{~mA}$ for 2 hours. DNA was visualized by EtBr, which was added directly to the gel $(0.5 \mu \mathrm{g} / \mu \mathrm{l})$ with the following evaluation on a UV transilluminator. A commercially provided synthetic $100 \mathrm{bp}$ marker was used as a DNA molecular weight standard.

For the verification of certain types of deletions, we used set Devyser AZF. The results were evaluated using the ABI 3130 genetic analyzer.

Patients who were diagnosed to have chromosomal abnormalities or Y chromosome microdeletions were given genetic counseling.

\section{RESULTS}

Of all cases, 226 (94.56\%) had normal karyotype (46, $\mathrm{XY}$ ) and 13 (5.44\%) had abnormal karyotype. Twelve of the chromosomal abnormalities were gonosomal in patients with Klinefelter syndrome $(47, \mathrm{XXY})$ and one was balanced reciprocal translocation involving autosomes 6,XY,t(15;16)(qter;p13). All patients with Klinefelter's syndrome were azoospermic. Y chromosome microdeletions were not found in any of the 12 azoospermic subjects with Klinefelter syndrome.

Among our 226 patients with azoospermia and with normal karyotype, 8 patients (mean age 30.6 years) had microdeletions in the AZF region of the $\mathrm{Y}$ chromosome (3.35\%). The set we used for detection of microdeletions contained sequences recommended by EAA and EMQN. These sequences cover all AZF subregions; sY84 and sY86 cover the AZFa subregion, sY127 and sY134 cover the AZFb subregion, sY254 and sY255 cover the AZFc subregion. Detailed deletion specifications of particular sequences are shown in (Table 1 and 2). Considering particular types of deletions we determined deletions in each region $\mathrm{AZFa}, \mathrm{b}, \mathrm{c}$ but also a complete deletion of the whole AZF region. It was shown that microdeletions in the AZFc sub-region were encountered more often than in $\mathrm{AZFb}$ and in $\mathrm{AZFa}$ sub-regions. We did not detect any deletion in AZF region in the control group of individuals.

Currently it is possible to perform deletion screening also with usage of the commercial fluorescent kits. We had a possibility to use a Devyser AZF kit to confirm deletions in the AZF region in patients with a confirmed deletion in the AZFc subregion (Fig. 1 and 2). We can confirm that this kit meets very good diagnostic criteria; the only disadvantage is the cost of examination, which is evidently higher in comparison to a primary PCR.

\section{DISCUSSION}

AZF deletions are deletions of the euchromatine part of the long arm of the Y chromosome. It is assumed that these deletions directly damage genes in this region that is responsible for the proper course of spermatogenesis. 
Table 1. Detailed deletion specifications of our 8 patients with azoospermia and microdeletions in AZF region of Y chromosome.

\begin{tabular}{|c|c|c|c|c|c|c|}
\hline & sY84 & sY86 & sY127 & sY134 & sY254 & sY255 \\
\hline & \multicolumn{2}{|c|}{ AZFa subregion } & \multicolumn{2}{|c|}{$\mathrm{AZFb}$ subregion } & \multicolumn{2}{|c|}{ AZFc subregion } \\
\hline Case 1 & & & & & del & del \\
\hline Case 2 & del & del & del & del & del & del \\
\hline Case 3 & & & del & del & del & del \\
\hline Case 4 & & & & & del & del \\
\hline Case 5 & & & & & del & del \\
\hline Case 6 & & del & & & & \\
\hline Case 7 & & del & & & & \\
\hline Case 8 & & & & & del & del \\
\hline
\end{tabular}

Table 2. Number of azoospermic patients with deletions in specific AZF subregion.

\begin{tabular}{|l|c|c|c|c|c|c|}
\hline & $\begin{array}{c}\text { only AZFa } \\
\text { subregion }\end{array}$ & $\begin{array}{c}\text { only AZFb } \\
\text { subregion }\end{array}$ & $\begin{array}{c}\text { only AZFc } \\
\text { subregion }\end{array}$ & $\begin{array}{c}\mathrm{AZFa}+\mathrm{b} \\
\text { subregions }\end{array}$ & $\begin{array}{c}\mathrm{AZFb}+\mathrm{c} \\
\text { subregions }\end{array}$ & $\begin{array}{c}\mathrm{AZFa}+\mathrm{b}+\mathrm{c} \\
\text { subregions }\end{array}$ \\
\hline $\begin{array}{l}\text { Number of patients } \\
\text { with deletion }\end{array}$ & 2 & 0 & 4 & 0 & 1 & 1 \\
\hline
\end{tabular}

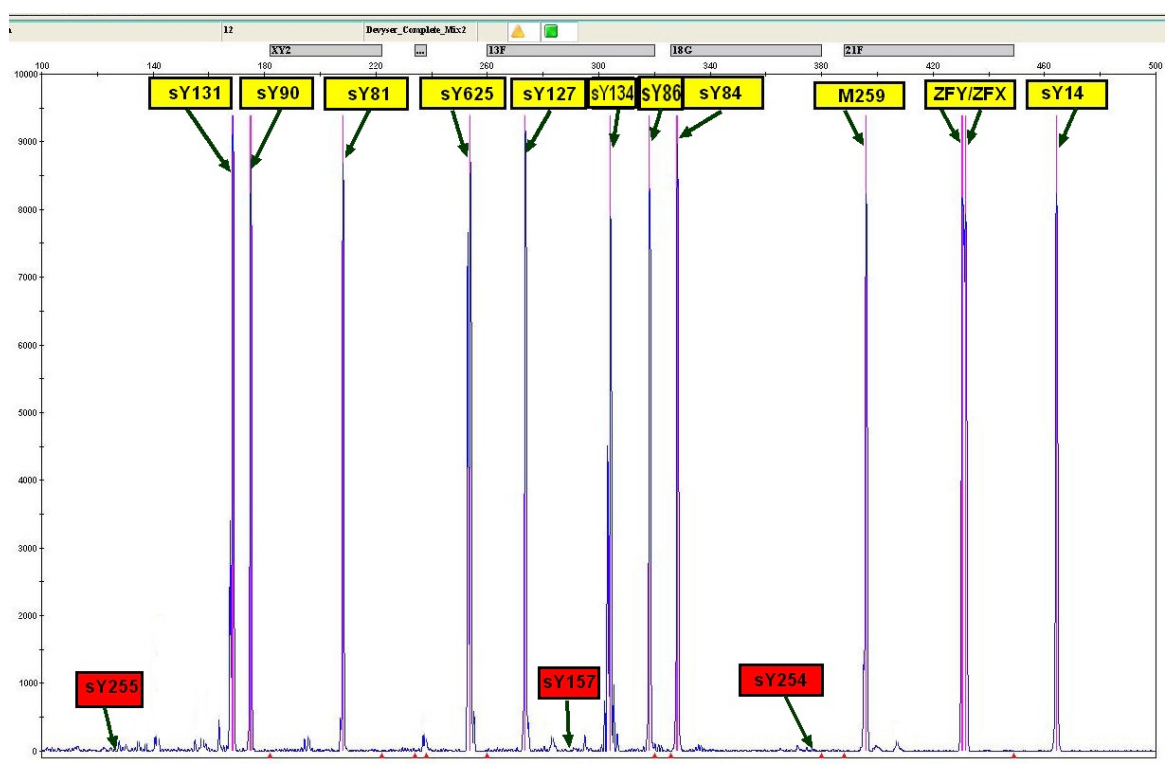

Fig. 1. Devyser AZF identification of STS markers provides clearly labeled data on the genetic analyzer-confirmed deletions of sY 255, sY 157, sY 254.

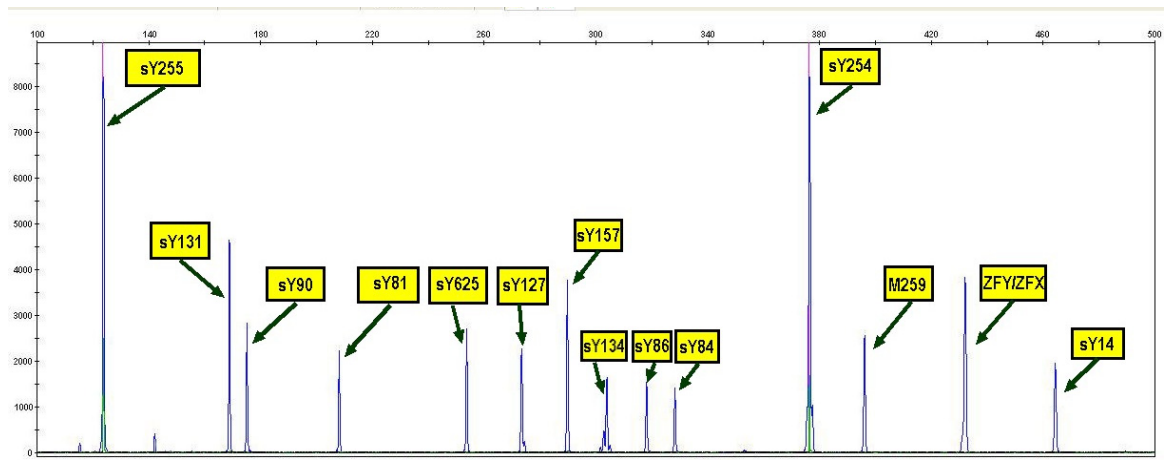

Fig. 2. Devyser AZF identification of STS markers provides clearly labeled data on the Genetic Analyzer. Positive control - health man. 
Y-chromosomal microdeletions are the second most frequent disorder of spermatogenesis in men with fertility disorder after Klinefelter's syndrome. In the last decade a number of research and clinical institutions have described screening of microdeletions in infertile men and molecular diagnostics of this type of Y-chromosomal impairment has become a significant diagnostic test within laboratories worldwide dealing with these problems ${ }^{15-17}$. Microdeletions in the AZF region are frequently found in patients with azoospermia. The incidence of these microdeletions has been found from 3 to $55 \%$ (ref. ${ }^{18,19}$ ). EAA and EMQN published the laboratory guidelines for molecular analysis of Y-chromosomal microdeletions ${ }^{14}$. Therefore we decided to use six sequences and proceed in accordance with European guidelines in which all three sub-regions are represented by Y sequences: sY84, sY86, sY127, sY134, sY254 and sY255.

The question arises whether it is possible to combine particular haplogroups within various male populations with disorders in spermatogenesis. It would be to some extent responsible for different types and frequencies of deletions considering the fact that particular genes in the given region encode proteins with a different function within different stages of spermatogenesis. It is assumed that also particular types of deletions correlate with various clinical features. Despite the specified criteria of sequence selection for the purpose of confirming deletions in the AZF region, in the literature we still find various values of frequencies during deletion screening, and not a clear genotype-phenotype correlation, which corresponds to our results. We reported deletions in the AZF region in $3.35 \%$ of patients with azoospermia when we used six Y-chromosome specific STS. Arruda et al. ${ }^{20}$ examined six
STS in 23 azoospermic patients from Brazil. They found microdeletions in $43.48 \%$ cases. SãoPedro et al. ${ }^{21}$ also examined Brazilian patients; they detected microdeletions in $6.7 \%$ based on 14 STS. However, Pina-Neto et al. ${ }^{22}$ found $6.6 \%$ microdeletions in all three AZF sub-regions using 28 STS in 60 infertile Brazilian men with azoospermia. Omrani et al. ${ }^{23}$ examined 60 patients with azoospermia from west Azerbaijan with a set of 20 Y-specific STS. They found deletions in $30 \%$ of cases. Kremer et al. ${ }^{24}$ found microdeletions in AZFc sub-region in $47.37 \%$ of patients from the Netherlands with azoospermia (total number of evaluated patients was 19). It is clear that the frequency of microdeletions in azoospermatic patients is variable (possible ethnic or geographic factor), but the most frequent place of deletions is the AZFc sub-region, as can be seen in our study, too (Table 3 ).

Klinefelter syndrome is the most common sex-chromosome abnormality in men ${ }^{25,26}$. This results in testicular failure, variable degrees of androgen deficiency and infertility. The mechanism by which chromosome abnormality leads to the spermatogenic defects remains unknown ${ }^{27}$. In our study we found 12 (5\%) cases with 47,XXY karyotype. Our results do not show microdeletion of $\mathrm{Y}$ chromosomes in patients with Klinefelter syndrome and are in accordance with the studies provided by Choe et al. ${ }^{28}$, Tateno et al. ${ }^{29}$, Lee et al. ${ }^{30}$ and Balkan et al. ${ }^{31}$.

De novo deletions of $\mathrm{Yq}$ are one of the most frequentlyoccurring chromosomal abnormalities in men and are believed to arise from recombination events between long stretches of highly repetitive DNA sequences during meiosis or early pre-implantation development ${ }^{32}$. Accordingly, Y chromosome microdeletions contribute only margin-

Table 3. AZF subregions of Y-chromosome DNA examination in azoospermic patients according to several authors (sorted by from the most numerous \% of deletion to the least numerous).

\begin{tabular}{|c|c|c|c|c|}
\hline Authors and country & $\begin{array}{c}\text { No. of examined } \\
\text { azoospermic } \\
\text { patients }\end{array}$ & $\begin{array}{l}\text { No. of patients } \\
\text { with microdele- } \\
\text { tion }\end{array}$ & $\%$ of deletion & $\begin{array}{c}\text { Most often } \\
\text { targeted AZF } \\
\text { subregion } \\
\end{array}$ \\
\hline $\begin{array}{l}\text { Foresta et a } 1^{18} \\
\text { Italy }\end{array}$ & 18 & 10 & $55.56 \%$ & - \\
\hline $\begin{array}{l}\text { Malekasgar and Mombaini }{ }^{35} \\
\text { Iran }\end{array}$ & 31 & 16 & $51.16 \%$ & $\mathrm{AZFc}$ \\
\hline $\begin{array}{l}\text { Kremer et } \mathrm{al}^{24} \\
\text { Netherland }\end{array}$ & 19 & 9 & $47.37 \%$ & $\mathrm{AZFc}$ \\
\hline $\begin{array}{l}\text { Arruda et } \mathrm{al}^{13} \\
\text { Brasilia }\end{array}$ & 23 & 10 & $43.48 \%$ & $\mathrm{AZFa}$ \\
\hline $\begin{array}{l}\text { Omrani et } \mathrm{al}^{23} \\
\text { Azerbaijan }\end{array}$ & 60 & 18 & $30.00 \%$ & $\mathrm{AZFc}$ \\
\hline $\begin{array}{l}\text { Ceylan et } \mathrm{al}^{36} \\
\text { Turkey }\end{array}$ & 30 & 5 & $16.67 \%$ & $\mathrm{AZFc}$ \\
\hline $\begin{array}{l}\text { SãoPedro et } \text { al }^{21} \\
\text { Brasilia }\end{array}$ & 29 & 2 & $6.90 \%$ & $\mathrm{AZFc}$ \\
\hline $\begin{array}{l}\text { Pina-Neto et } \mathrm{al}^{22} \\
\text { Brasilia }\end{array}$ & 60 & 4 & $6.67 \%$ & $\mathrm{AZFc}$ \\
\hline $\begin{array}{l}\text { Our results } \\
\text { Slovakia }\end{array}$ & 239 & 8 & $3.35 \%$ & $\mathrm{AZFc}$ \\
\hline $\begin{array}{l}\text { Balkan et } \mathrm{al}^{31} \\
\text { Turkey }\end{array}$ & 52 & 1 & $1.9 \%$ & $\mathrm{AZFc}$ \\
\hline
\end{tabular}


ally to the totality of human male infertility but when present, the introduction of intracytoplasmic sperm injection (ICSI) as an artificial reproduction technique may allow for the transmission of such mutations to the next generation $^{33,34}$.

Using the set of sequences according to EAA and EMQN we have found deletions in subregions AZFa, AZFbc and AZFc, but also a complete deletion of the whole AZF region. In the AZFa region we observed a deletion of sequence sY86 even in two cases. To confirm whether it is a partial deletion of the region and where the breakpoints are, a more detailed analysis of the particular region would be needed. However, from the clinical point of view it is not necessary. We confirmed a deletion of the AZFc subregion represented by sequences sY254 and sY255 in three patients. Two patients had a combined deletion $\mathrm{AZFb} / \mathrm{c}$ and one patient had a deletion of the whole region. Further experience would be interesting particularly in the group of patients with various forms of oligospermia.

Currently it is possible to perform deletion screening also by using fluorescent kits. We had a possibility to use a Devyser AZF kit to confirm deletions in the AZF region in patients with detected deletions in the $A Z F c$ subregion. We can confirm that this kit meets very good diagnostic criteria; the only disadvantage is the cost of examination, which is evidently higher in comparison to the primary PCR.

Deletions in the AZF region of the $\mathrm{Y}$ chromosome are specific within diagnoses with spermatogenesis disorders, no deletions were recorded in the group of normospermic men. From this point of view it is more appropriate to indicate that microdeletions of the $\mathrm{Y}$ chromosomal AZF region are more responsible for oligo or azoospermia than for the cause of infertility. Many couples undergo a genetic consultation before using various forms of IVF. Despite the fact that it is not possible to clearly determine an exact phenotype of male offspring of men with confirmed deletions (different genetic background, environmental factors affect fertility potential of fathers and sons), it is possible to draw attention to some facts during consultations. Apart from possible oligospermia or azoospermia there is a potential risk of developing an anomaly 45,X0 Turner syndrome, or other forms of sex chromosome mosaicism, including hermaphroditism. Yq deletions are associated with Y chromosome instability. We can say that identification of Y chromosomal microdeletions has significant diagnostic and prognostic value and provides useful information for genetic counseling in these patients.

In conclusion, our study confirmed that detection of microdeletions of the AZF region in Slovak azoospermic patients is rare (only $3.35 \%$ of patients with azoospermia) but important for a prognostic view.

\section{REFERENCES}

1. McElreavey K, Krausz C, Bishop CE. The human Y chromosome and male infertility. Results Probl Cell Differ 2000;28:211-32.

2. Li Z, Haines ChJ, Han Y. "Micro-deletions" of the human Y chromosome and their relationship with male infertility. J Genet Genomics 2008;35:193-9.

3. Sadeghi-Nejad H, Farrokhi F. Genetics of azoospermia: current knowledge, clinical implications, and future directions. Part II. Y chromosome microdeletions. Urol J 2007;4:192-206.

4. Tiepolo L, Zuffardi O. Localization of factors controlling spermatogenesis in the nonfluorescent portion of the human Y chromosome long arm. Hum Genet 1976;34:119-24.

5. Foresta C, Moro E, Ferlin A. Y chromosome microdeletions and alterations of spermatogenesis. Endocr Rev 2001;22:226-39.

6. Ferlin A, Moro E, Rossi A, Dallapiccola B, Foresta C. The human $\mathrm{Y}$ chromosome's azoospermia factor $\mathrm{b}(\mathrm{AZFb})$ region: sequence, structure, and deletion analysis in infertile men. J Med Genet 2003;40:18-24.

7. Vogt PH, Edelmann A, Kirsch S, Henegariu O, Hirschmann P, Kiesewetter F, Köhn FM, Schill WB, Farah S, Ramos C, Hartmann M, Hartschuh W, Meschede D, Behre HM, Castel A, Nieschlag E, Weidner W, Gröne HJ, Jung A, Engel W, Haidl G. Human Y chromosome azoospermia factors (AZF) mapped to different subregions in Yq11. Hum Mol Genet 1996;5:933-43.

8. Kamp C, Huellen K, Fernandes S, Sousa M, Schlegel PN, Mielnik A, Kleiman S, Yavetz H, Krause W, Küpker W, Johannisson R, Schulze W, Weidner W, Barros A, Vogt PH. High deletion frequency of the complete AZFa sequence in men with Sertoli-cellonly syndrome. Molec Hum Reprod 2001;7:987-94.

9. Kuroda-Kawaguchi T, Skaletsky H, Brown LG, Minx PJ, Cordum HS, Waterston RH, Wilson RK, Silber S, Oates R, Rozen S, Page DC. The AZFc region of the $\mathrm{Y}$ chromosome features massive palindromes and uniform recurrent deletions in infertile men. Nature Genet 2001;29:279-86.

10. Skaletsky H, Kuroda-Kawaguchi T, Minx PJ, Cordum HS, Hillier L, Brown LG, Repping S, Pyntikova T, Ali J, Bieri T, Chinwalla A, Delehaunty A, Delehaunty K, Du H, Fewell G, Fulton L, Fulton R, Graves T, Hou SF, Latrielle P, Leonard S, Mardis E, Maupin R, McPherson J, Miner T, Nash W, Nguyen C, Ozersky P, Pepin K, Rock S, Rohlfing T, Scott K, Schultz B, Strong C, Tin-Wollam A, Yang SP, Waterston RH, Wilson RK, Rozen S, Page DC. The male - specific region of the human $\mathrm{Y}$ chromosome is a mosaic of discrete sequence classes. Nature 2003;423:825-37.

11. Ferrás C, Fernandes S, Marques CJ, Carvalho F, Alves C, Silva J, Sousa M, Barros A. AZF and DAZ gene copy-specific deletion analysis in maturation arrest and Sertoli cell-only syndrome. Mol Hum Reprod 2004;10:755-61.

12. Foresta C, Garolla A, Bartoloni L, Bettella A, Ferlin A. Genetic abnormalities among severely oligospermic men who are candidates for intracytoplasmic sperm injection. J. Clin Endocrinol Metab 2005;90:152-6.

13. Arruda JT, Bordin BM, Santos PR, Mesquita WE, Silva RC, Maia MC, Approbato MS, Florêncio RS, Amaral WN, Rocha Filho MA, Moura KK. Y chromosome microdeletions in Brazilian fertility clinic patients. Gen Mol Res 2007;6(2):461-9.

14. Simoni S, Bakker E, Krausz C. EAA/EMQN best practice guidelines for molecular diagnosis of Y-chromosomal microdeletions. State of the art 2004. Int J Androl 2004;27:240-9.

15. Ferlin A, Arredi B, Speltra E, Cazzadore C, Selice R, Garolla A, Lenzi A, Foresta C. Molecular and clinical characterization of Y chromosome microdeletions in infertile men: A 10-year experience in Italy. J Clin Endocrinol Metab 2007;92:762-70.

16. Maurer B, Gromoll J, Simoni M, Nieschlag E. Prevalence of Y chromosome microdeletions in infertile men who consulted a tertiary care medical centre: the Munster experience. Andrologia 2001;33:27-33.

17. Vogt PH. AZF deletions and $\mathrm{Y}$ chromosomal haplogroups: history and updates on sequence. Hum Reprod 2005;11:319-36.

18. Foresta C, Ferlin A, Garolla A, Moro E, Pistorello M, Barbaux S, Rossato M. High frequency of well-defined Y-chromosome 
deletions in idiopathic Sertoli cell-only syndrome. Hum Reprod 1998;13:302-7.

19. Vogt PH. Molecular genetics of human male infertility: from genes to new therapeutic perspectives. Curr Pharm Des 2004;10:471-500.

20. Arruda JT, Bordin BM, Santos PR, Mesquita WE, Silva RC, Maia MC, Approbato MS, Florêncio RS, Amaral WN, Rocha Filho MA, Moura KK. Y chromosome microdeletions in Brazilian fertility clinic patients. Genet Mol Res 2007;6(2):461-9.

21. SãoPedro SL, Fraietta R, Spaine D, Porto CS, Srougi M, Cedenho AP, Avellar MC. Prevalence of Y chromosome deletions in a Brazilian population of non-obstructive azoospermic and severely oligozoospermic men. Braz J Med Biol Res 2003;36:787-93.

22. Pina-Neto JM, Carrara RC, Bisinella R, Mazzucatto LF, Martins MD, Sartoratto E, Yamasaki R. Somatic cytogenetic and azoospermia factor gene microdeletion studies in infertile men. Braz J Med Biol Res 2006;39:555-61.

23. Omrani MD, Samadzadae S, Bagheri M, Attar K. Y chromosome microdeletions in idiopathic infertile men from west Azarbaijan. Urol J 2006;3(1):38-43.

24. Kremer JA, Tuerlings JH, Meuleman EJ, Schoute F, Mariman E, Smeets DF, Hoefsloot LH, Braat DD, Merkus HM. Microdeletion of the $\mathrm{Y}$ chromosome and intracytoplasmic sperm injection: from gene to clinic. Hum Reprod 1997;12(4):687-91.

25. Vojtassák J, Malová J, Demjenová L, Martanovic P, Böhmer D, Korbel M, Danihel L, Fiala P, Duríková M, Braxatorisová T, Geislerová V, Pagácová E. Developmental defects and chromosomal aberrations in spontaneous abortions and stillbirths. Gen Physiol Biophys 1999;18:182-88.

26. Vojtaššák J, Böhmer D. Cytogenetika opakovaných samovolných potratov (Article in Slovak, Cytogenetics in recurrent spontaneous abortions). Prakt Gynekol 1995;2(2):98-101.
27. Amory JK, Anawalt BD, Paulsen CA, Bremmer WJ. Klinefelter's syndrome. Lancet 2000;356:333-5.

28. Choe JH, Kim JW, Lee JS, Seo JT. Routine screening for classical azoospermia factor deletions of $\mathrm{Y}$ chromosome in azoospermic patients with Klinefelter syndrome. Asian J Androl 2007;9(6):81520.

29. Tateno T, Sasagawa I, Ichiyanagi O, Ashida J, Nakada T, Saito H, Hiroi M. Microdeletions of the DAZ (deleted in azoospermia) gene or the YRRM (Y chromosome ribonucleic acid recognition motif) gene does not occur in patients with Klinefelter's syndrome with and without spermatogenesis. Fertil Steril 1999;71:746-9.

30. Lee YH, Kim T, Kim MH, Kim YT, Kim SH. Y chromosome microdeletions in idiopathic azoospermia and non-mosaic type of Klinefelter syndrome. Exp Mol Med 2000;32:231-4.

31. Balkan M, Tekes S, Gedik A. Cytogenetic and Y chromosome microdeletion screening studies in infertile males with oligozoospermia and azoospermia in Southeast Turkey. J Assist Reprod Genet 2008;25:559-65.

32. Edwards RG, Bishop CE. On the origin and frequency of Y chromosome deletions responsible for male infertility. Mol Hum Reprod 1997;3:549-54.

33. Gazvani R, Lewis-Jones DI. Cystic fibrosis mutation screening before assisted reproduction. Int J Androl 2004;27:1-4.

34. Poongothai J, Gopenath T S, Manonayaki S. Genetics of human male infertility. Singapore Med J 2009;50(4):336-46.

35. Malekasgar AM, Mombaini H. Screening of ' $\mathrm{Y}$ ' chromosome microdeletions in Iranian infertile males. J Hum Reprod Sci 2008;1(1):2-9.

36. Ceylan GG, Ceylan C, Elyas H. Genetic anomalies in patients with severe oligozoospermia and azoospermia in eastern Turkey: a prospective study. Genet Mol Res 2009;8(3):915-22. 